\title{
Transforming assessment practices in a higher education institution
}

\section{Tomas, Carmen}

Teaching Transformation, University of Nottingham, United Kingdom

\begin{abstract}
A review of institutional practices is presented to elicit the extent to which assessment practices really align with the principles of the standards-based paradigm. An institutional case presents the creation of a framework for practice and its use in evaluating institutional practices. Insights at institutional level suggest that mainstream practices and cultural change may need transformation. In particular, design, student engagement, marking and review of assessments may require strengthening. The ensuing institutional agenda to address central areas of concern have evolved into a range of institution-wide initiatives. The case illustrates how faculty and centre projects may work together to enhance the shared understanding of institutional "good" assessment practice and the development of communities of practice.
\end{abstract}

Keywords: criterion referenced assessment; validity; assessment frameworks; institutional transformation. 


\section{Introduction}

A paradigmatic shift during the 90s concerning assessment practice saw the introduction of the standards-based paradigm for practice. This move entailed fundamental changes leaving the measurement model behind. The purpose of assessment shifted from selection to learning; the method of assessment shifted from comparing student against peers to assessing against set standards and criteria (Taylor 1994). The paradigmatic shift during the 90s was of global reach. Several phenomena reported in the literature may suggest that principles of the standards-based paradigm may not be fully adhered to in practice. Ongoing tensions between the two paradigms, and resulting incoherence in practice, has also been widely discussed (Elton and Johnston 2002; Yorke 2011; Medland 2016; Boud 2017).

Key studies and voices in the literature over a few decades show some warning signs of tensions in practice, absence of clarity in some areas. Grade inflation has been reported as a challenging issue (Bachan 2015), the gaps in stablishing a learning culture in assessment are repeatedly highlighted (Jessop and Tomas 2017; Jessop and Maleckar 2016; Jessop, ElHakim and Gibbs 2014) and lastly, the absence of clear standards in marking is also of concern (Bloxham, Hughes and Aide 2016; Boud 2017).

It is felt that establishing with greater confidence the nature of this misalignment between practice and the standards model of assessment may require more specific work. Few crossinstitutional studies are available. A closer investigation is needed to establish how most productively assessment practices need developing to really align with the tenets of the standards referenced paradigm. An institutional case will aim to suggest ways of gauging the distance between principles of the standards based model and dominant practices. An illustration of how this can serve to influence institutional agendas and projects on change is presented.

\section{An institutional framework to understand mainstream assessment practice}

A unitary framework for practice is proposed that addresses the principles of validity in standards-based assessment. Messick's theoretical breakdown of validity (1994, 1995, 1996) considers a breakdown into steps in practice. Table 1 below maps the theoretical concepts in an assessment life-cycle framework and with proposed steps.

A series of evaluations drawing from key representatives of Faculties, across the university, has enabled the identification of mainstream steps and common considerations in practice. These are summarized in the column that indicates whether considerations expressed are commonly considered in steps that are required. This is indicated as common. Optional indicates where some practices or considerations may be left to practitioners. Unknown designates practices that are not considered at all and absent. 
Whilst the proposed framework is an idealized model, the institutional summary of typical considerations reveal several limitations and areas where institutional enhancement of practices and transformation needs to take place.

Table 1 Articulation in practice of the theoretical construct and operationalisation of validity

\begin{tabular}{|c|c|c|c|}
\hline $\begin{array}{l}\text { Assessment life- } \\
\text { cycle stage }\end{array}$ & $\begin{array}{l}\text { Validity } \\
\text { element }\end{array}$ & Step in practice & $\begin{array}{l}\text { Common } \\
\text { practice }\end{array}$ \\
\hline \multirow[t]{6}{*}{ Design stage } & \multirow[t]{3}{*}{ Content } & Selection of an assessment method (task) & Common \\
\hline & & $\begin{array}{l}\text { Task analysis determining the knowledge } \\
\text { and skills to be revealed in the tasks - } \\
\text { Evaluative criteria (overall attributes } \\
\text { required of the student) }\end{array}$ & $\begin{array}{l}\text { Optional or } \\
\text { unknown }\end{array}$ \\
\hline & & $\begin{array}{l}\text { Revision of assessment tasks that assess the } \\
\text { same construct across a programme of } \\
\text { study }\end{array}$ & $\begin{array}{l}\text { Optional or } \\
\text { unknown }\end{array}$ \\
\hline & \multirow[t]{3}{*}{ Structural } & Quality levels and sources of difficulty & Optional \\
\hline & & $\begin{array}{l}\text { Determining sources of difficulty of } \\
\text { different criteria in a task }\end{array}$ & Optional \\
\hline & & $\begin{array}{l}\text { Definition of combination rules (e.g. } \\
\text { scoring strategy) } \\
\text { Minimising construct irrelevant difficulty }\end{array}$ & Optional \\
\hline $\begin{array}{l}\text { Communication, } \\
\text { support and } \\
\text { engagement }\end{array}$ & $\begin{array}{l}\text { Structural } \\
\text { and } \\
\text { consequen } \\
\text { tial }\end{array}$ & $\begin{array}{l}\text { Increase student familiarisation to reduce } \\
\text { anxiety } \\
\text { Communicate to students criteria and } \\
\text { levels; Engage students in understanding } \\
\text { quality }\end{array}$ & Optional \\
\hline $\begin{array}{l}\text { Pre-marker } \\
\text { training }\end{array}$ & Structural & $\begin{array}{l}\text { Staff familiarisation: Check interpretations } \\
\text { of levels of performance (inter-marker) }\end{array}$ & Optional \\
\hline Marking & Structural & $\begin{array}{l}\text { Ensure consistency during marking (intra- } \\
\text { marker) }\end{array}$ & Optional \\
\hline $\begin{array}{l}\text { Feedback and } \\
\text { marks }\end{array}$ & $\begin{array}{l}\text { Consequen } \\
\text { tial }\end{array}$ & $\begin{array}{l}\text { Provision of meaningful feedback and } \\
\text { criteria }\end{array}$ & $\begin{array}{l}\text { Common } \\
\text { (various } \\
\text { approaches) }\end{array}$ \\
\hline $\begin{array}{l}\text { Post-marking } \\
\text { moderation }\end{array}$ & Structural & $\begin{array}{l}\text { Revision of scoring of assessment and } \\
\text { identify rival explanations for results }\end{array}$ & $\begin{array}{l}\text { Common } \\
\text { (various } \\
\text { approaches) }\end{array}$ \\
\hline Review of task, & External & External validity of marks (analyses) (e.g. & Unknown \\
\hline
\end{tabular}


Transforming assessment practices in a higher education institution

\begin{tabular}{|c|c|c|c|}
\hline \multirow[t]{4}{*}{$\begin{array}{l}\text { rubrics and } \\
\text { results }\end{array}$} & & $\begin{array}{l}\text { how well marks relate to other related } \\
\text { tasks) } \\
\text { Consistency of marks with other } \\
\text { performances (for an individual) }\end{array}$ & \\
\hline & $\begin{array}{l}\text { Substantiv } \\
\text { e }\end{array}$ & $\begin{array}{l}\text { Evidence base for task analysis and } \\
\text { structural validity (post-hoc analyses) }\end{array}$ & Optional \\
\hline & Content & Revision of assessment design & Optional \\
\hline & $\begin{array}{l}\text { Consequen } \\
\text { tial }\end{array}$ & $\begin{array}{l}\text { Student perception of the value of } \\
\text { assessments } \\
\text { Impact on self-assessment ability, } \\
\text { motivation, lifelong learning and reflection } \\
\text { skills }\end{array}$ & Optional \\
\hline $\begin{array}{l}\text { High stakes } \\
\text { decisions }\end{array}$ & $\begin{array}{l}\text { Generaliza } \\
\text { bility }\end{array}$ & $\begin{array}{l}\text { Consideration of similar tasks, different } \\
\text { assessors and consideration of the } \\
\text { consistency of student performance to drive } \\
\text { final decisions on degree classifications }\end{array}$ & Unknown \\
\hline
\end{tabular}

\section{The institutional transformation project}

Based on the framework for practice, a purposeful programme of transformation work has been conducted. Particular stages, based on the evaluation that required revision were prioritised: design, student engagement and review stages. Priorities are ranked in order of importance as well as feasibility:

- Engagement of students in advance of assessments: communication, practice and active engagement are fundamental for practice

- Enhancing the transparency of standards, expectations and marking (design stage)

- Programme level assessment: load, design, consistency of practice

Institutional transformation is a slow process requiring multiple steps. The process of transformation has involved locally led projects with the support of the centre in setting agendas and developing the models. The phases of institutional transformation are laid out below:

Initial phase: 2014 to present (ongoing)

- Step 1 Development of the theory based framework for performance based assessments (centrally) as detailed above. 
- Step 2 Agenda setting, exploration of local practice and needs Institutional consolidation, growth and ongoing exploration (2016 onwards)

- Step 3 Assessment framework endorsed as a university level framework.

- Step 4 Ongoing liaison with Schools/Faculties and launching of new projects

- Step 5 Ongoing exploration and experimentation of alternative practices and models (e.g. moderation; peer assessment and evaluative judgement)

\section{Outcomes}

The framework for practice has been instrumental in enabling and supporting institutional and local strategic decisions. Local autonomy and decision making are central to the institutional approach whilst, centrally, support is offered with models and assistance with local developments. Some of the central gains include:

- greater understanding of practices

- greater consistency and growing a community of practice

- alignment of assurance reviews and systems

This joined up effort is essential to retain the essence of the principles in practice but also to enable, as an institution, to develop and share greater understanding of practice. The work is still in progress but the impact is visible with Faculty and School-wide cases of transformation of practice in place.

\section{References}

Bachan, Ray. 2015. “Grade Inflation In UK Higher Education.” Studies in Higher Education. doi: 10.1080/03075079.2015.1019450.

Bloxham, Susan, Claire Hughes, and Lenore Adie. 2016. "What's The Point Of Moderation? A Discussion Of The Purposes Achieved Through Contemporary Moderation Practices.” Assessment and Evaluation In Higher Education 41 (4): 638-653.

Boud, D.J. 2017, 'Standards-based assessment for an era of increasing transparency' in Scaling up Assessment for Learning in Higher Education, Springer. 
Elton, Lewis and Brenda Johnston. 2002. "Assessment in Universities: A Critical Review of Research." Learning and Teaching Support Network. https://eprints.soton.ac.uk/59244/1/59244.pdf.

Jessop, T., Y. El Hakim, and G. Gibbs. 2014. "The Whole is Greater Than the Sum of Its Parts: A Large-scale Study of Students' Learning in Response to Different Programme Assessment Patterns.” Assessment \& Evaluation in Higher Education 39 (1): 73-88. doi:10.1080/02602938.2013.792108.

Jessop, T., and B. Maleckar. 2016. "The Influence of Disciplinary Assessment Patterns on Student Learning: A Comparative Study.” Studies in Higher Education 41 (4): 696-711. doi:10.1080/03075079.2014.943170.

Jessop, T., and C. Tomas. 2017. "The Implications of Programme Assessment Patterns for Student Learning.” Assessment \& Evaluation in Higher Education 42 (6): 990-999. doi:10.1080/02602938.2016.1217501.

Medland, Emma. 2016. "Assessment In Higher Education: Drivers, Barriers And Directions For Change In The UK." Assessment and Evaluation in Higher Education 41 (1): 81-96.

Messick, Samuel. 1994. "The Interplay of Evidence and Consequences in the Validation of Performance Assessments.” Educational Researcher 23(2):13-23.

Messick, Samuel. 1995. "Validity Of Psychological Assessment: Validation Of Inferences From Persons' Responses And Performances As Scientific Inquiry Into Score Meaning.” American psychologist 50(9): 741-749.

Messick, Samuel. 1996. "Validity in Performance Assessments". In Technical Issues in Large-scale Performance Assessment edited by Gary W. Phillips, 1-18. Washington DC: National Centre for Educational Statistics.

Taylor, Catherine. 1994. "Assessment for Measurement of Standards: The Peril and Promise of Large-Scale Assessment Reform.” American Educational Research Journal 31 (2): 231-262. doi: 10.3102/00028312031002231.

Yorke, Mantz. 2011. "Summative Assessment: Dealing With The Measurement Fallacy." $\begin{array}{lllll}\text { Studies in Higher } & \text { Education } 36 & \text { (3): 251-273. }\end{array}$ http://dx.doi.org/10.1080/03075070903545082 